\title{
BIOLOGICAL, SOCIAL, AND ECONOMIC RISK FACTORS OF CHILD TUBERCULOSIS IN SURAKARTA CENTRAL JAVA: A MULTIPLE LOGISTIC REGRESSION
}

\author{
Dyah Ayu Saputri'), Yulia Lanti Retno Dewi'), Bhisma Murti') \\ ${ }^{1)}$ Masters Program in Public Health, Universitas Sebelas Maret \\ 2)Faculty of Medicine, Universitas Sebelas Maret
}

\begin{abstract}
Background: Tuberculosis (TB) disease in children under 15 years (pediatric TB) is a public health problem of special significance because it is a marker for recent transmission of TB. This study aimed to analyze biological, social, and economic risk factors of child TB. Subjects and Method: A case control study was carried out at 25 villages in Surakarta, from August to September 2019. A sample of 200 chilren aged o-18 years was selected by fixed disease sampling. The dependent variable was TB. The independent variables were birthweight, BCG immunization, exclusive breastfeeding, nutritional status, family income, smoke exposure, family history of TB. Data on TB cases were obtained from medical record. The other variables were collected by questionnaire. The data were analyzed by a multiple logistic regression.

Results: The risk of TB increased with poor house sanitation $(\mathrm{OR}=4.50 ; 95 \% \mathrm{CI}=1.18$ to $17.12 ; \mathrm{p}=0.027)$, smoke exposure $(\mathrm{OR}=4.13 ; 95 \% \mathrm{CI}=1.05$ to $16.22 ; \mathrm{p}=0.042)$, and had history of $\mathrm{TB}(\mathrm{OR}=5.54 ; 95 \% \mathrm{CI}=1.49$ to $20.61 ; \mathrm{p}=0.011)$. The risk of TB decreased with normal birthweight $\geq 2,500 \mathrm{~g}(\mathrm{OR}=0.18 ; 95 \% \mathrm{CI}=0.05$ to $0.57 ; \mathrm{p}=0.003)$, $\mathrm{BCG}$ immunization $(\mathrm{OR}=0.18 ; 95 \% \mathrm{CI}=0.06$ to $0.58 \mathrm{p}=0.004)$, exclusive breastfeeding $(\mathrm{OR}=$ $0.11 ; 95 \% \mathrm{CI}=0.02$ to $0.55 ; \mathrm{p}=0.006)$, good nutritional status $(\mathrm{OR}=0.10 ; 95 \% \mathrm{CI}=0.02$ to $0.48 ; \mathrm{p}=0.004)$, and family income $\geq \mathrm{Rp} 1,802,700(\mathrm{OR}=0.09 ; 95 \% \mathrm{CI}=0.02$ to $0.36 ; \mathrm{p}=$ 0.001).

Conclusion: The risk of TB increases with poor house sanitation, smoke exposure, and had history of TB. The risk of TB decreases with normal birthweight $\geq 2,500 \mathrm{~g}$, BCG immunization, exclusive breastfeeding, good nutritional status, and high family income.
\end{abstract}

Keywords: Tuberkulosis, biological, sosial dan ekonomi.

\section{Correspondence:}

Dyah Ayu Saputri. Masters Program in Public Health, Universitas Sebelas Maret. Jl. Ir. Sutami 36A, Surakarta 57126, Central Java, Indonesia. Email: ayusaputridyah7@gmail.com. Mobile: o81353236388.

The $7^{\text {th }}$ International Conference on Public Health

Solo, Indonesia, November 18-19, 2020 | 90

https://doi.org/10.26911/the7thicph.01.45 